\title{
High-Temperature Surface Oxide Growth Kinetics of Al-Si-Zr Bulk Alloys and Ribbons
}

\author{
Denitsa Kiradzhiyska $^{1}\left(\mathbb{D}\right.$, Gueorgui Vassilev $^{2}\left(\mathbb{D}\right.$, Rositsa Mancheva ${ }^{1}$, Svetlana Yaneva ${ }^{3}$ and Nikolina Milcheva ${ }^{1, * \mathbb{D}}$ \\ 1 Department of Chemical Sciences, Faculty of Pharmacy, Medical University of Plovdiv, 15A Vassil Aprilov \\ blvd., 4000 Plovdiv, Bulgaria; denitsa.kiradzhiyska@mu-plovdiv.bg (D.K.); r_manch@abv.bg (R.M.) \\ 2 Department of General and Inorganic Chemistry, Methodology of Chemical Education, University of Plovdiv \\ Paisii Hilendarski, 4000 Plovdiv, Bulgaria; gpvassilev@gmail.com \\ 3 Acad. A. Balevski Institute of Materials Science, BAS, 1574 Sofia, Bulgaria; syaneva1@gmail.com \\ * Correspondence: nikolina.milcheva@mu-plovdiv.bg
}

Citation: Kiradzhiyska, D.; Vassilev,

G.; Mancheva, R.; Yaneva, S.;

Milcheva, N. High-Temperature

Surface Oxide Growth Kinetics of Al-Si-Zr Bulk Alloys and Ribbons. Metals 2021, 11, 1893. https:// doi.org/10.3390/met11121893

Academic Editor:

Isaac Toda-Caraballo

Received: 2 November 2021

Accepted: 23 November 2021

Published: 25 November 2021

Publisher's Note: MDPI stays neutral with regard to jurisdictional claims in published maps and institutional affiliations.

Copyright: (C) 2021 by the authors. Licensee MDPI, Basel, Switzerland. This article is an open access article distributed under the terms and conditions of the Creative Commons Attribution (CC BY) license (https:// creativecommons.org/licenses/by/ $4.0 /)$.

\begin{abstract}
A typical modification technique of the functional properties of Al-Si based alloys is the addition of some third element in trace level. In the present work, ternary $\mathrm{Al}-\mathrm{Si}-\mathrm{Zr}$ bulk and ribbon alloys have been prepared. The kinetics of high-temperature surface oxidation has been studied by thermogravimetric method. It was found that at the start of the experiment the chemical reaction velocity is rate-controlling while for longer times the (oxygen) diffusion is the rate-controlling process. Activation energy of the two stages of oxidation has been obtained. Additional studies such as thermochemical analysis, optical and electron microscopy, and microhardness tests have been done.
\end{abstract}

Keywords: Al-Si-Zr bulk alloys and rapidly solidified ribbons; thermochemical and thermogravimetric analysis; kinetics of high-temperature oxidation

\section{Introduction}

The Al-Si alloys have found many applications, mostly in airspace, marine and automotive industries. It is known that the corrosion resistance of these materials is due to the oxide layer naturally formed on their surfaces during the interaction with the oxygen and humidity of the air.

Dotting Al-Si alloys with some third constituent might change some of their properties (especially the mechanical properties and the oxidation resistance). Recently, some new cast Al-alloys [1] and Al-Si-alloys with zirconium additions were designed [2,3]. This transition metal affects the mechanical properties of the cast alloys by diminishing the grain size and by the formation of intermetallic compounds [4]. Moreover, it was found that the improvement of the mechanical properties of different $\mathrm{Al}-\mathrm{Mg}-\mathrm{Si}$ modified cast alloys by adding $\mathrm{Zr}$ is due to the effect of fine-grain strengthening [5-8].

$\mathrm{Zr}$ solubility (at room temperature) in the fcc-Al phase (denoted further as (Al) or matrix-phase) is rather small [9-13] and intermetallic compounds (mainly $\mathrm{Al}_{3} \mathrm{Zr}$ ) are formed, commonly, when the solubility limit is exceeded. Nine more intermetallic compounds (IMC) have been reported for the Al-Zr system [13]. Thus, binary Si-Zr and $\mathrm{Al}-\mathrm{Zr} \mathrm{IMC}$ are expected to appear in the investigated Al-Si-Zr alloys as well as ternary phases, eventually, in agreement with the relevant phase diagrams. It is also known that silicon atoms can partially substitute aluminium in the compound $\mathrm{Al}_{3} \mathrm{Zr}$ [14]. Nevertheless, experimental information for the ternary $\mathrm{Al}-\mathrm{Si}-\mathrm{Zr}$ system is scarce and available only at temperatures above $700{ }^{\circ} \mathrm{C}$ [12,15-17].

The surface oxidation kinetics of a metal or alloy is controlled by a number of processes such as chemical reaction rate at one or both interfaces (metal/oxide or oxide/gas) and by atomic (ionic) transport through the oxide layer [18].

Studies of the micro-structural development in Al-Si microcrystalline alloys [19,20] and their oxidation mechanism have been performed by Yaneva et al. [21] It has been found 
that zirconium does not take part in the oxide layer formation and that $\mathrm{Al}_{2} \mathrm{O}_{3}$ layers grows onto the aluminium solid solution as well as onto the silicon phase interfaces. The oxide layers can break in adjacency to zirconium intermediate phases, allowing direct interaction of the metal surface with air, thus complicating the oxidation process. Nonetheless, the formal oxide layers formation kinetics of Al-Si-Zr alloys has not been studied.

Thus, the main goal of the current work is to investigate the surface oxide layers formation kinetics of $\mathrm{Al}-\mathrm{Si}-\mathrm{Zr}$ bulk alloys and ribbons and, in some extent, to characterize their phase composition.

\section{Materials and Methods}

In order to prepare ternary Al-Si-Zr alloys in two different forms (bulk alloys and ribbons), pure aluminium and silicon have been melted together in an inert atmosphere at $800{ }^{\circ} \mathrm{C}$. Thereafter, zirconium containing ligature $(4.2 \mathrm{wt} . \% \mathrm{Zr})$ has been added in order to get the desired $\mathrm{Zr}$ contents. The melted alloys were poured, from $930-950{ }^{\circ} \mathrm{C}$, into metal moulds. As-obtained master alloys were solidified at air.

Ribbon-like Al-Si-Zr samples ( $\approx 15 \mathrm{~mm}$ wide and $\approx 25-40 \mu \mathrm{m}$ thick) have been prepared from the respective master alloys by flat-flow casting, as previously described $[12,17]$. The cooling velocity was in the interval of $10^{5}$ to $10^{6} \mathrm{~K} / \mathrm{s}$. The casting has been done at the Institute of Metal Science and Technology, Bulgarian Academy of Sciences, Sofia.

Silicon and zirconium contents have been thereafter determined by wet chemistry and spectral methods at the Institute of Inorganic Chemistry, Bulgarian Academy of Sciences. Inductively Coupled Plasma Optical Emission Spectrometry (ICP-OES, iCAP 6000 series, produced by Thermo Scientific, Waltham, MA, USA) was used in order to determine experimentally $\mathrm{Zr}$ contents of the alloys.

Thermochemical analyses of these "as cast" ribbons have been done using Netzsch STA 449 F3 Jupiter apparatus under helium flux. Two regimes (Differential Scanning Calorimetry (DSC) and Differential Thermal Analysis (DTA)) have been applied depending on the samples behaviour. Three consecutive runs have been done with each sample. Heating rates of $10 \mathrm{deg} / \mathrm{min}$ and cooling rates of $40 \mathrm{deg} / \mathrm{min}$ have been commonly applied. The highest temperatures of heating were $1500^{\circ} \mathrm{C}$ and $1550{ }^{\circ} \mathrm{C}$ for DTA and DSC studies, respectively.

The kinetics of high-temperature surface oxidation has been studied by a thermogravimetric method. These experiments were performed with a LABSYS-EVO device (Lyon, France). The main working temperature was $540{ }^{\circ} \mathrm{C}$ although experiments were done at 490,510 and $560{ }^{\circ} \mathrm{C}$ as well. The work temperatures were maintained at an interval of $\pm 5{ }^{\circ} \mathrm{C}$.

The duration of each trial was $90 \mathrm{~min}$. Initially, inert gas (Ar) flow was passed through the system until the desired working temperature was obtained. Thereafter, synthetic air (containing 20 vol. \% oxygen) under pressure of $1 \times 10^{5} \mathrm{~Pa}$ was passed with a volume rate of $20 \mathrm{~cm}^{3} / \mathrm{min}$. The dimensions of the ribbon and bulk samples used for the kinetic studies were approximately $2 \mathrm{~mm} \times 4 \mathrm{~mm}$. The thickness of the bulk samples was approximately $1 \mathrm{~mm}$, while this of the ribbons was around $25-40 \mu \mathrm{m}$. The weights of the samples used for the thermogravimetric experiments varied from 15 to $90 \mathrm{mg}$.

The equations describing the oxidation rates might be commonly classified as logarithmic, parabolic and linear [21-23]. One should be aware that they represent only limiting or ideal cases and deviations are often encountered, thus the kinetic data fitting to simple rate equations might become a challenge.

The direct logarithmic- and the inverse-logarithmic rate laws are encountered, usually, at relatively low oxidation temperatures (i.e., below $400{ }^{\circ} \mathrm{C}$ ) [22]. At high temperatures the oxidation rate usually follows parabolic time dependence (Equation (1)).

$$
W^{n}=k_{j}\left(t+t_{0}\right)+C
$$

The symbol $W$ might represent the oxide layer thickness (for example see [23]) but in the case considered in the current work, $W$ represents the weight gain (due to the 
oxygen mass entered the respective samples), $n$ is the exponent (theoretically having the value of 2 for the parabolic rate law), $t$ denotes the oxidation time, $s, t_{0}$ is the eventual incubation period, $\mathrm{s}$ (usually appearing to be negligibly small), $k_{j}$ represents the respective rate constants, and $C$ is an integration constant. As previously mentioned, the quantity $W$ ought to be normalized (i.e., its dimension has to be $\mathrm{kg} / \mathrm{m}^{2}$ ) in order to ensure the compatibility between all thermogravimetric experimental data.

The parabolic growth rate signifies that a volume diffusion process determines the overall velocity of the oxidation. Such a process may imply a uniform diffusion of one or more of the reactants through the growing layer. In the case of a linear oxidation rate, the power $n$ is equal to 1 and entails that a surface or phase boundary process or reaction is rate limiting.

The microhardness of specimens was determined by Vickers method using Digital Micro Vickers Hardness Tester TMVS-1 (TIME High Technology Ltd., Beijing, China) with intender load of $0.025 \mathrm{~kg}$ and a time of $10 \mathrm{~s}$. The microhardness measurements are converted to MPa dimensions, for convenience.

Optical (Olympus BX61 with video camera DP70 (Olympus, Tokyo, Japan) and motorized examination table) and scanning electron microscope (SEM) techniques were used for microstructure studies. The latter is a JEOL apparatus, type JSM 6390 (JEOL Inc., Tokyo, Japan). The chemical composition of selected spots was measured by means of energydispersive spectroscopy (EDS) analysis (EDS Oxford INCA device (Oxford Instruments, Abingdon, UK) operated at $20 \mathrm{kV}$ ).

\section{Results and Discussion}

\subsection{Chemical Composition of the Alloy}

The experimentally obtained chemical compositions are given in Table 1. Si and $\mathrm{Zr}$ contents of the master alloys and $\mathrm{Zr}$ contents of all samples have been determined directly. As one can see $\mathrm{Zr}$ contents vary from $0.26 \mathrm{wt}$.\% to $1.38 \mathrm{wt}$.\% received by means of ICP-OES, which is in good agreement with the other values of $\mathrm{Zr}$ obtained by wet chemistry and spectral methods (Table 1). Other studies with the described compositions have been done in our previous works [24,25]. It is essential to note that the chemical compositions of all samples investigated in this work are near to that of the Al-Si eutectic point (i.e., $12.6 \mathrm{wt} . \%$ $\mathrm{Si}[11])$. Thus, the samples can be classified as hypoeutectic, with reference to the binary Al-Si system.

Table 1. Experimentally determined chemical compositions of the master alloys and ribbons. $\mathrm{N}^{\mathrm{B}}$ and $\mathrm{N}^{\mathrm{R}}$-consecutive number of the master (bulk) alloys and of the respective ribbons; $\mathrm{c}_{\mathrm{Si}}-\mathrm{Si}$ content of the master alloy (mass \%); $\mathrm{C} \mathrm{Zr}-\mathrm{Zr}$ content of the master alloy and the respective ribbon (mass \%); $\mathrm{c}_{\mathrm{Al}}$ —estimated aluminum content; RSD—relative standard deviation (mass \%) of the chemical compositions.

\begin{tabular}{|c|c|c|c|c|c|c|c|}
\hline \multicolumn{4}{|c|}{ Wet Chemistry and Spectral Methods } & \multicolumn{4}{|c|}{ ICP-OES Methods } \\
\hline $\mathbf{N}^{\mathbf{B}}$ & $\begin{array}{c}\mathrm{C}_{\mathrm{Si}} \\
(\text { Mass } \%)\end{array}$ & $\begin{array}{c}\mathrm{c}_{\mathrm{Zr}} \\
(\text { Mass \%) }\end{array}$ & $\begin{array}{c}\mathrm{c}_{\mathrm{Al}} \\
(\text { Mass \%) }\end{array}$ & $\mathbf{N}^{\mathrm{B}}$ & $\begin{array}{c}\mathrm{c}_{\mathrm{Zr}} \pm \mathrm{RSD} \\
\text { (Mass \%) }\end{array}$ & $\mathbf{N}^{\mathrm{R}}$ & $\begin{array}{c}\mathrm{c}_{\mathrm{Zr}} \pm \mathrm{RSD} \\
\text { (Mass \%) }\end{array}$ \\
\hline $1^{\mathrm{B}}$ & 9.70 & 0.30 & 90.00 & $1^{\mathrm{B}}$ & $0.26 \pm 0.01$ & $1^{\mathrm{R}}$ & $0.27 \pm 0.01$ \\
\hline $2^{\mathrm{B}}$ & 10.00 & 0.82 & 89.18 & $2^{\mathrm{B}}$ & $0.99 \pm 0.06$ & $2^{\mathrm{R}}$ & $1.09 \pm 0.08$ \\
\hline $3^{\mathrm{B}}$ & 11.30 & 1.20 & 87.50 & $3^{\mathrm{B}}$ & $1.19 \pm 0.05$ & $3^{\mathrm{R}}$ & $1.16 \pm 0.07$ \\
\hline $4^{\mathrm{B}}$ & 9.30 & 1.40 & 89.30 & $4^{\mathrm{B}}$ & $1.38 \pm 0.06$ & $4^{\mathrm{R}}$ & $1.34 \pm 0.03$ \\
\hline
\end{tabular}

\subsection{Oxidation Kinetics}

The thermogravimetric experiments allow registering of the sample mass growth at isothermal conditions. The experimental data have been normalized by converting the absolute mass growth $(\mathrm{kg})$ to mass growth per unite area $\left(\mathrm{kg} / \mathrm{m}^{2}\right)$. The quantity obtained in this way is referred to further as "normalized weight change". It has been assumed that the mass change is due to the surface oxide layers formation on the samples. The experimental conditions of the thermogravimetric tests are shown in Table 2. Both types of 
samples (bulk and ribbon) have been oxidized at similar conditions. In order to study the kinetics of high-temperature oxidation, thermogravimetric tests at different temperatures were done.

Table 2. Experimental conditions of the thermogravimetric tests with bulk alloys $\left(\mathrm{N}^{\mathrm{B}}\right)$ and ribbons $\left(\mathrm{N}^{\mathrm{R}}\right)$. Temperature $(t)$ in ${ }^{\circ} \mathrm{C}$ and respective standard deviation (SD).

\begin{tabular}{cccccc}
\hline $\mathbf{N}^{\mathbf{B}}$ & $\begin{array}{c}\boldsymbol{t} \pm \mathbf{S D} \\
\left({ }^{\circ} \mathbf{C}\right)\end{array}$ & $\begin{array}{c}\text { Duration } \\
\mathbf{( s )}\end{array}$ & $\mathbf{N}^{\mathbf{R}}$ & $\begin{array}{c}\boldsymbol{t} \pm \mathbf{S D} \\
\left({ }^{\circ} \mathbf{C}\right)\end{array}$ & $\begin{array}{c}\text { Duration } \\
(\mathbf{s})\end{array}$ \\
\hline $1^{\mathrm{B}}$ & $541.4 \pm 0.4$ & 5400 & $1^{\mathrm{R}}$ & $540.4 \pm 0.4$ & 5400 \\
$2^{\mathrm{B}}$ & $541.4 \pm 0.4$ & 5400 & $2^{\mathrm{R}}$ & $540.7 \pm 0.4$ & 5400 \\
$3^{\mathrm{B}}$ & $541.3 \pm 0.4$ & 5352 & $3^{\mathrm{R}}$ & $541.4 \pm 0.4$ & 5400 \\
$3^{\mathrm{B}}$ & $540.6 \pm 0.3$ & 7200 & - & - & - \\
$4^{\mathrm{B}}$ & $541.3 \pm 0.4$ & 5400 & $4^{\mathrm{R}}$ & $541.0 \pm 0.4$ & 5400 \\
$3^{\mathrm{B}}$ & $490.0 \pm 0.4$ & 5400 & $3^{\mathrm{R}}$ & $490.0 \pm 0.4$ & 5400 \\
$3^{\mathrm{B}}$ & $510.0 \pm 0.4$ & 5400 & $3^{\mathrm{R}}$ & $510.0 \pm 0.4$ & 5400 \\
$3^{\mathrm{B}}$ & $560.0 \pm 0.4$ & 5400 & - & - & - \\
\hline
\end{tabular}

We would like to note that, in a number of cases, the thermogravimetric experiments have been considered as "unsuccessful" because of arbitrary shapes of the registered curves. The latter have often exhibited very low oxidation rates, in comparison to the "successful" runs. The reasons for these divergences could not be revealed. The amount of the conditionally "unsuccessful" experiments was around 50\% of all trials.

The oxidation kinetic curves registered with the bulk number 3 (at 490, 510, 540 and $560^{\circ} \mathrm{C}$ ) are shown in Figure 1a, while the pertinent results obtained for ribbon number 3 are plotted in Figure 1b.

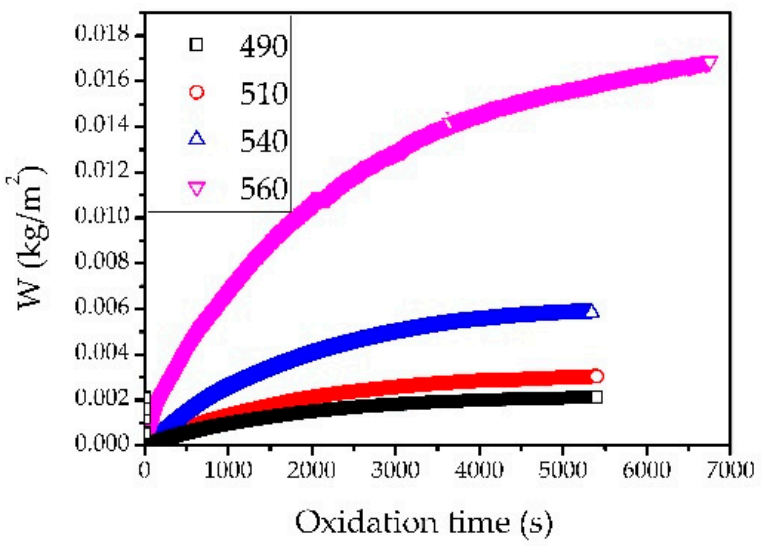

(a)

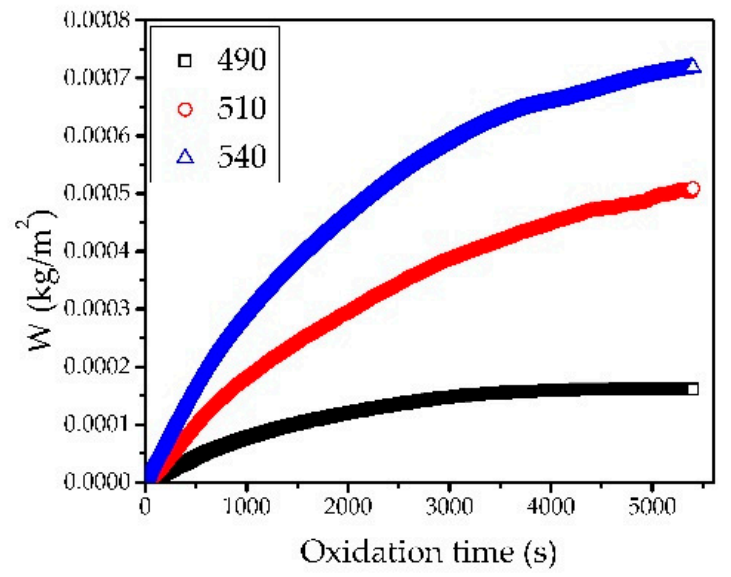

(b)

Figure 1. Oxidation kinetic curves registered with: (a) the bulk sample number 3 at 490, 510, 540 and $560{ }^{\circ} \mathrm{C}$; (b) the ribbon sample number 3 at 490,510 and $540{ }^{\circ} \mathrm{C}$. Normalized weight changes $\left(W, \mathrm{~kg} / \mathrm{m}^{2}\right)$ are plotted along the ordinate and the oxidation time (s) along the abscissa.

One can see (Figure 1a,b) that the oxidation kinetic curves start developing since the very beginning of the experiments, which means that there is no incubation period (i.e., the parameter $t_{0}$ (Equation (1)) is equal to zero). It is notable, by the values of $W$, that the oxidation process is more intensive with bulk alloy than ribbons, and therefore the rapidly solidified ribbons are more stable in oxidation.

In order to calculate the exponent $n$ using the oxidation rate Equation (1) the normalized mass changes $W\left(\mathrm{~kg} / \mathrm{m}^{2}\right)$, have been plotted against the oxidation time $t(\mathrm{~s})$, in 
logarithmic coordinates (see Figure 2a,b) and linear regression analyses have been done.

These estimations are done in this study for both bulk alloys and ribbons.

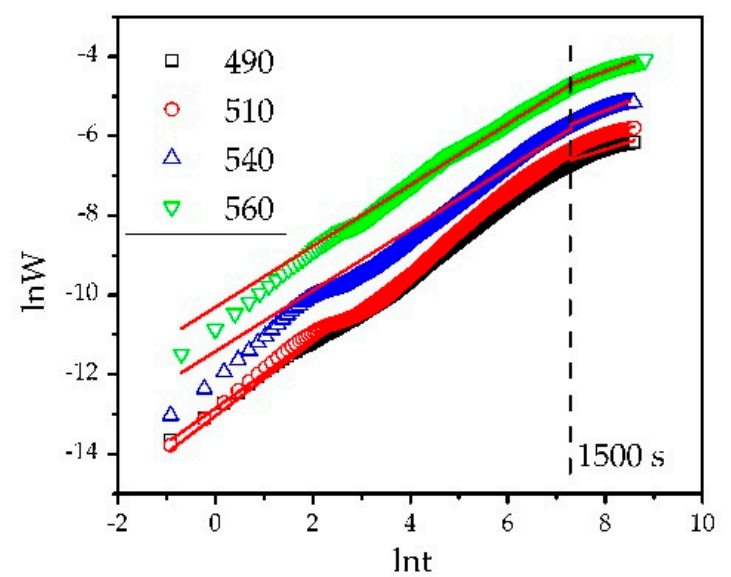

(a)

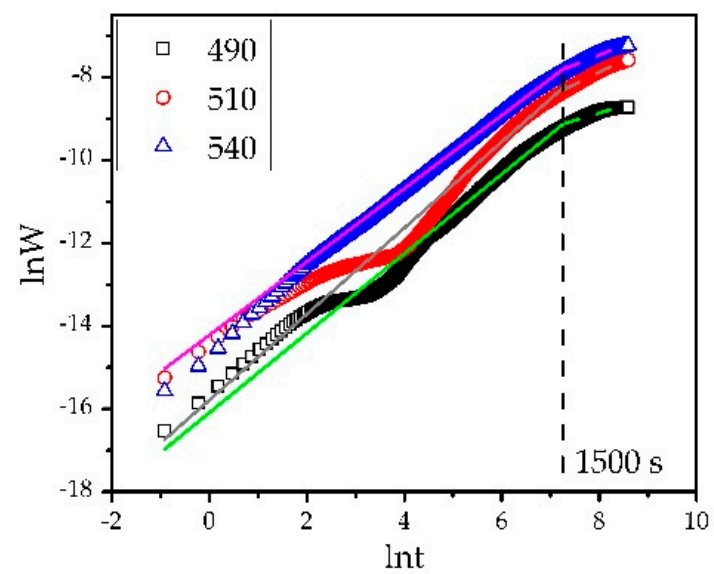

(b)

Figure 2. Natural logarithm of the normalized weight $\left(W, \mathrm{~kg} / \mathrm{m}^{2}\right)$ along the ordinate and natural logarithm of time $(t, \mathrm{~s})$ are plotted along the abscissa of (a) a bulk number 3 at $490,510,540$ and $560{ }^{\circ} \mathrm{C}$ and (b) a ribbon number 3 at 490,510 and $540{ }^{\circ} \mathrm{C}$.

In these coordinates, the $n$ values are represented by the slopes of the respective lines. It has been found that, generally, parabolic rate kinetics (i.e., $n=2$ ) is obeyed at longer times, but some consistent deviations for the initial annealing times were observed. Thus, we have assumed (and thereafter we have proved it, see Table 3) that the experimental thermogravimetric curves reflect two consecutive stages. Initially (up to $1500 \mathrm{~s}$ ), the linear oxidation rate law $(n=1)$ is valid, while for longer times the parabolic rate law (i.e., $n=2$ ) is followed. The value of $1500 \mathrm{~s}$ has been selected by the trial and error method and is, surely, somewhat approximate.

Table 3. Exponent values $\left(n_{\mathrm{i}}\right)$ of Equation (1) and the respective standard deviations $\left(\mathrm{SD}_{\mathrm{i}}\right)$ for bulk $\left({ }^{\mathrm{B}}\right)$ and ribbon $\left({ }^{\mathrm{R}}\right)$ samples at various temperatures $\left(t,{ }^{\circ} \mathrm{C}\right)$, obtained in logarithmic coordinates. No-sample number, $n_{1}$ and $n_{2}$-exponent values for the time intervals $0-1500 \mathrm{~s}$ and $1500-5400 \mathrm{~s}$, respectively. $k_{1 \text {, ef }}\left(\mathrm{kg} / \mathrm{m}^{2} \mathrm{~s}\right)$ and $k_{2 \text {, ef }}\left(\mathrm{kg} / \mathrm{m}^{2} \mathrm{~s}\right)$ represent the effective oxidation rate constants for the first and second time periods, in that order.

\begin{tabular}{|c|c|c|c|c|c|}
\hline No & $\begin{array}{c}t \\
\left({ }^{\circ} \mathrm{C}\right)\end{array}$ & $n_{1} \pm \mathrm{SD}_{\mathrm{n} 1}$ & 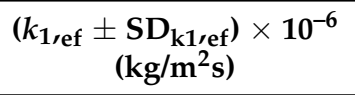 & $n_{2} \pm \mathrm{SD}_{\mathrm{n} 2}$ & $\begin{array}{c}k_{2, \text { ef }} \pm \mathrm{SD}_{\mathrm{k} 2 \text {,ef }} \\
\left(\mathrm{kg} / \mathrm{m}^{2} \mathrm{~s}\right)\end{array}$ \\
\hline $1^{\mathrm{B}}$ & 540 & $0.998 \pm 0.002$ & $1.887 \pm 0.020$ & $2.120 \pm 0.004$ & $(2.230 \pm 0.060) \times 10^{-9}$ \\
\hline $2^{B}$ & 540 & $1.106 \pm 0.002$ & $0.758 \pm 0.030$ & $2.108 \pm 0.004$ & $(2.900 \pm 0.060) \times 10^{-9}$ \\
\hline $3^{\mathrm{B}}$ & 540 & $1.135 \pm 0.001$ & $1.158 \pm 0.010$ & $2.397 \pm 0.004$ & $(9.530 \pm 0.140) \times 10^{-10}$ \\
\hline $4^{\mathrm{B}}$ & 540 & $1.140 \pm 0.001$ & $0.870 \pm 0.030$ & $2.391 \pm 0.004$ & $(5.680 \pm 0.070) \times 10^{-10}$ \\
\hline $3^{\mathrm{B}}$ & 490 & $1.146 \pm 0.001$ & $0.355 \pm 0.003$ & $2.630 \pm 0.005$ & $(1.930 \pm 0.030) \times 10^{-11}$ \\
\hline $3^{\mathrm{B}}$ & 510 & $1.072 \pm 0.002$ & $0.841 \pm 0.010$ & $2.530 \pm 0.005$ & $(8.840 \pm 0.130) \times 10^{-11}$ \\
\hline $3^{\mathrm{B}}$ & 560 & $1.300 \pm 0.002$ & $1.499 \pm 0.010$ & $2.225 \pm 0.003$ & $(2.000 \pm 0.020) \times 10^{-8}$ \\
\hline $1^{\mathrm{R}}$ & 540 & $1.031 \pm 0.001$ & $0.199 \pm 0.003$ & $1.858 \pm 0.003$ & $(3.056 \pm 0.060) \times 10^{-10}$ \\
\hline $2^{R}$ & 540 & $1.091 \pm 0.001$ & $0.176 \pm 0.004$ & $2.362 \pm 0.004$ & $(1.100 \pm 0.020) \times 10^{-11}$ \\
\hline $3^{R}$ & 540 & $1.132 \pm 0.001$ & $0.102 \pm 0.006$ & $2.143 \pm 0.004$ & $(3.852 \pm 0.002) \times 10^{-11}$ \\
\hline $4^{\mathrm{R}}$ & 540 & $1.097 \pm 0.002$ & $0.930 \pm 0.004$ & $2.269 \pm 0.004$ & $(2.940 \pm 0.020) \times 10^{-11}$ \\
\hline $3^{R}$ & 490 & $1.043 \pm 0.002$ & $0.051 \pm 0.001$ & $2.816 \pm 0.004$ & $(4.788 \pm 0.003) \times 10^{-15}$ \\
\hline $3^{R}$ & 510 & $0.964 \pm 0.002$ & $0.245 \pm 0.002$ & $1.743 \pm 0.004$ & $(3.578 \pm 0.001) \times 10^{-10}$ \\
\hline
\end{tabular}

These findings mean that, at the start of the experiment, the chemical reaction (CR) velocity is rate-controlling (i.e., it is slower than the diffusion), while for longer times the (oxygen) diffusion (D) is the rate-controlling process. Such a sequence of the rate- 
controlling processes is physically justified because the oxygen influx is obstructed with the augmentation of the oxidized areas of the materials.

The oxidation kinetic constants $\left(k_{1}=k_{\mathrm{CR}}\right.$ and $\left.k_{2}=k_{\mathrm{D}}\right)$ obtained with bulk and ribbon samples, respectively, are plotted in Arrhenius coordinates (Figures 3 and 4). The oxide growth activation energy $\left(E_{\mathrm{A}}\right)$ for the two stages of the oxidation reaction for bulks and ribbons (first stage $0-1500 \mathrm{~s}$ process controlled by chemical reaction, second stage 1500-5600 s process controlled by diffusion) has been calculated by regression analyses. The logarithms of the oxidation kinetic constants and estimated activation energies for the both stages of bulks and ribbons are compiled in Table 4a,b. It is notable that the activation energy of the first time period (0-1500 s) is greater than the second one (1500-5600 s) for all samples. That difference for bulk samples is 5 times higher, while for the ribbons is about 4.5 times higher, which is of the same order. This means that the activation energy of the diffusion process is greater. The uncertainty of the activation energy for ribbons can be explained by assuming that they are nonhomogeneous nanomicrocrystal systems. This is supported by the SEM analyses [26], which proved that nano- and microsized Zr-enriched phases are formed in the Al-Si-Zr ribbons.

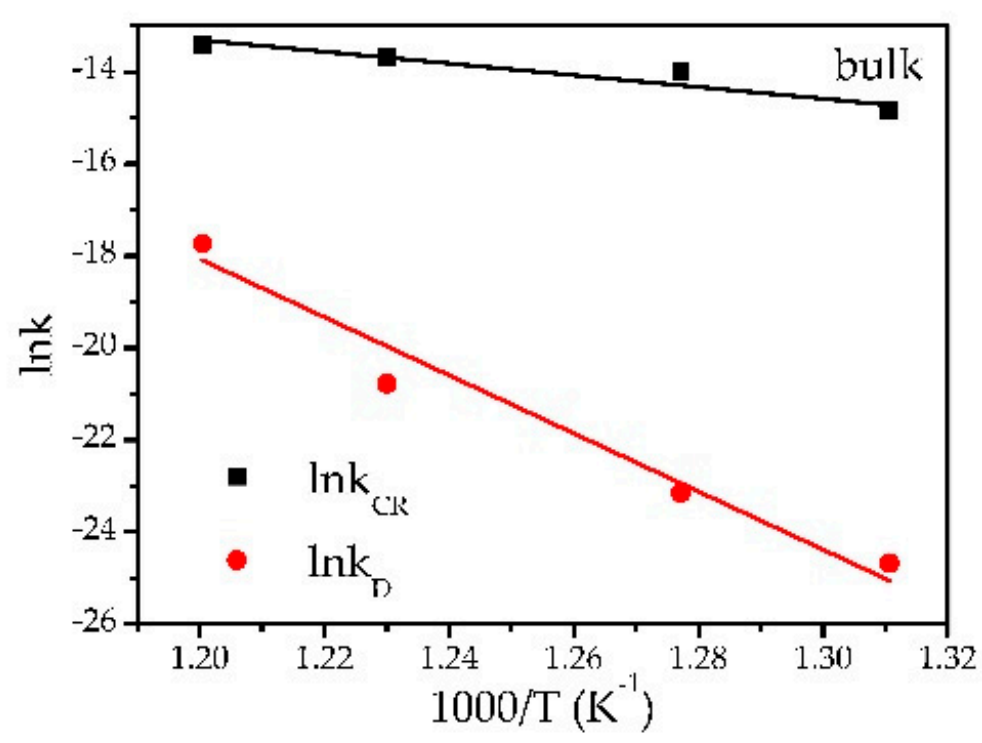

Figure 3. Arrhenius plot of the oxidation coefficients $\left(k_{\mathrm{CR}}, \mathrm{kg} / \mathrm{m}^{2}\right.$-oxidation coefficient of chemical reaction stage from 0 to $1500 \mathrm{~s}$ and $k_{\mathrm{D}}, \mathrm{kg} / \mathrm{m}^{2}$ - oxidation coefficient of diffusion stage from 1500 to $5400 \mathrm{~s}$ ) at various temperatures $(\mathrm{T}, \mathrm{K})$ for estimation of the activation energy of the two stages (CR and D) with bulk sample 3.

\subsection{Thermal Studies}

The thermal effects registered during heating and cooling of a given sample are related to the corresponding phase boundary crossing. That is why the phase diagrams of the systems involved in the studies are used as references. Thus, literature phase equilibrium data $[11,13,15]$ have been used to provide information for the binary end-systems ( $\mathrm{Al}-\mathrm{Si}$, $\mathrm{Al}-\mathrm{Zr}$, and $\mathrm{Si}-\mathrm{Zr}$ ) in order to identify the thermal effects related to the crossing of the invariants or the phase field boundaries.

The results of DTA experiments with Al-Si-Zr bulk samples (nos. $1^{\mathrm{B}}, 2^{\mathrm{B}}, 4^{\mathrm{B}}$ ) at heating (h) and at cooling (c) are shown in Table 5 (for DTA experiments) and in Table 6 (for DSC experiments). DTA curves have been represented in Figure 5 (heating) while DSC curves are shown in Figure 6. 


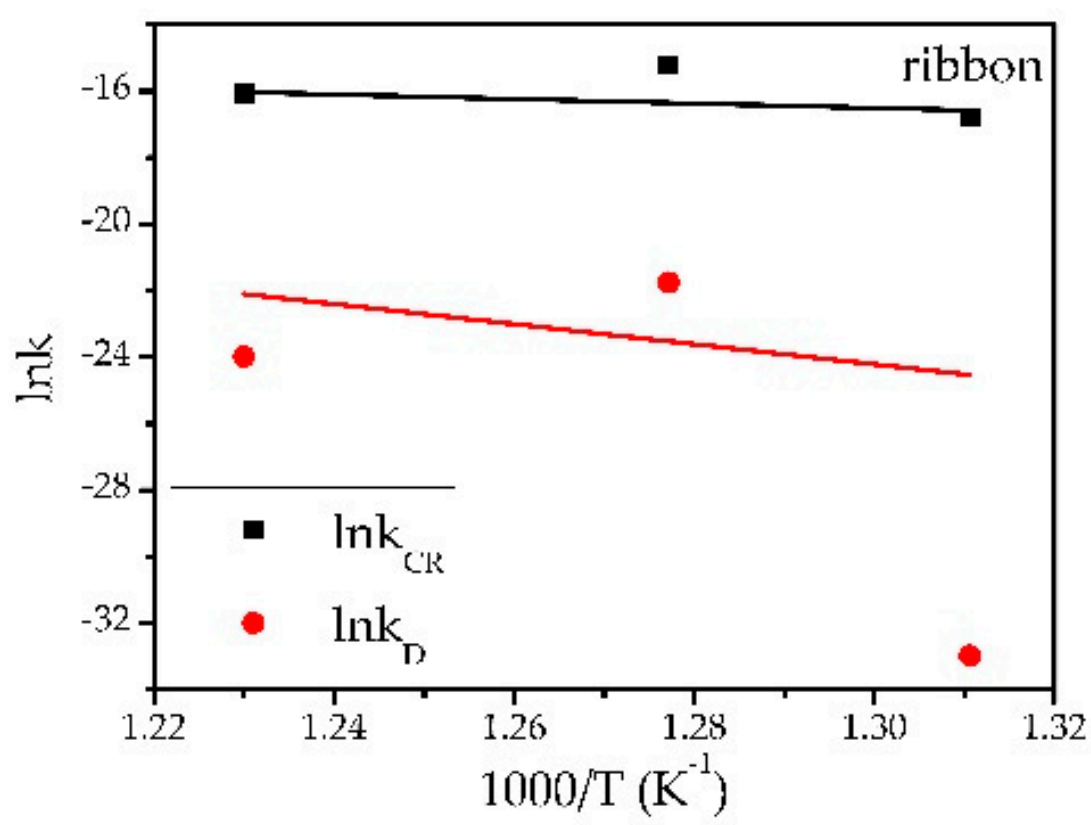

Figure 4. Arrhenius plot of the oxidation coefficients $\left(k_{\mathrm{CR}}, \mathrm{kg} / \mathrm{m}^{2}\right.$-oxidation coefficient of chemical reaction stage from 0 to $1500 \mathrm{~s}$ and $k_{\mathrm{D}}, \mathrm{kg} / \mathrm{m}^{2}$-oxidation coefficient of diffusion stage from 1500 to $5400 \mathrm{~s}$ ) at various temperatures $(\mathrm{T}, \mathrm{K})$ for estimation of the activation energy of the two stages (CR and D) with ribbon sample 3.

Table 4. Reaction rate constants $k_{\mathrm{CR}}$ (for the time intervals 0-1500 s) and $k_{\mathrm{D}}$ (for the time intervals 1500-5400 s) of (a) bulk and (b) ribbon samples at various temperatures and the respective activation energies $\left(E_{\mathrm{A}, \mathrm{CR}}, E_{\mathrm{A}, \mathrm{D}}\right)$ in $\mathrm{kJ} / \mathrm{mol}, \mathrm{R}$-correlation coefficient, $t$-temperature in ${ }^{\circ} \mathrm{C}$, SD—standard deviation, $\mathrm{kJ} / \mathrm{mol}$.

(a)

\begin{tabular}{|c|c|c|c|c|c|}
\hline No & $\begin{array}{c}t \\
\left({ }^{\circ} \mathrm{C}\right)\end{array}$ & $\ln k_{\mathrm{CR}} \pm \mathrm{SD}$ & $\ln k_{\mathrm{D}} \pm \mathrm{SD}$ & $\begin{array}{c}E_{\mathrm{A}, \mathrm{CR}} \pm \mathrm{SD} \\
(\mathrm{kJ} / \mathrm{mol})\end{array}$ & $\begin{array}{c}E_{\mathrm{A}, \mathrm{D}} \pm \mathrm{SD} \\
(\mathrm{kJ} / \mathrm{mol})\end{array}$ \\
\hline $3^{\mathrm{B}}$ & 490 & $-14.8501 \pm 0.0067$ & $-24.6708 \pm 0.0146$ & \multirow{4}{*}{$\begin{array}{c}106.30 \pm 20.45 \\
R^{2}=0.896\end{array}$} & \multirow{4}{*}{$\begin{array}{c}525.20 \pm 64.85 \\
R^{2}=0.955\end{array}$} \\
\hline $3^{\mathrm{B}}$ & 510 & $-13.9881 \pm 0.0089$ & $-23.1497 \pm 0.0144$ & & \\
\hline $3^{\mathrm{B}}$ & 540 & $-13.6688 \pm 0.0062$ & $-20.7716 \pm 0.0142$ & & \\
\hline $3^{\mathrm{B}}$ & 560 & $-13.4102 \pm 0.0077$ & $-17.7294 \pm 0.0106$ & & \\
\hline $1^{\mathrm{B}}$ & 540 & $-13.1797 \pm 0.0078$ & $-19.9213 \pm 0.0137$ & - & - \\
\hline $2^{B}$ & 540 & $-14.0926 \pm 0.0071$ & $-19.6584 \pm 0.0121$ & - & - \\
\hline $4^{\mathrm{B}}$ & 540 & $-13.9528 \pm 0.0081$ & $-21.2880 \pm 0.0120$ & - & - \\
\hline \multicolumn{6}{|c|}{ (b) } \\
\hline No & $\begin{array}{c}t \\
\left({ }^{\circ} \mathrm{C}\right)\end{array}$ & $\ln k_{\mathrm{CR}} \pm \mathrm{SD}$ & $\ln k_{\mathrm{D}} \pm \mathrm{SD}$ & $\begin{array}{c}E_{\mathrm{A}, \mathrm{CR}} \\
(\mathrm{kJ} / \mathrm{mol})\end{array}$ & $\underset{(\mathrm{kJ} / \mathrm{mol})}{E_{\mathrm{A}, \mathrm{D}}}$ \\
\hline $3^{R}$ & 490 & $-16.7894 \pm 0.0087$ & $-32.9727 \pm 0.0234$ & \multirow{3}{*}{$\begin{array}{c}56.26 \pm 9.88 \\
\mathrm{R}^{2}=0.360\end{array}$} & \multirow{3}{*}{$\begin{array}{c}250.92 \pm 123.37 \\
R^{2}=0.887\end{array}$} \\
\hline $3^{R}$ & 510 & $-15.2211 \pm 0.0155$ & $-21.7510 \pm 0.0082$ & & \\
\hline $3^{R}$ & 540 & $-16.0989 \pm 0.0057$ & $-23.9799 \pm 0.0131$ & & \\
\hline $1^{\mathrm{R}}$ & 540 & $-15.4276 \pm 0.0157$ & $-21.9093 \pm 0.0117$ & - & - \\
\hline $2^{\mathrm{R}}$ & 540 & $-15.5500 \pm 0.0167$ & $-25.2330 \pm 0.0257$ & - & - \\
\hline $4^{\mathrm{R}}$ & 540 & $-15.4594 \pm 0.0127$ & $-24.2498 \pm 0.0241$ & - & - \\
\hline
\end{tabular}


Table 5. Results of DTA experiments with Al-Si-Zr samples $1^{\mathrm{B}}, 2^{\mathrm{B}}, 4^{\mathrm{B}}$ at heating $\left(\mathrm{No}_{h}\right)$ and cooling $\left(\mathrm{No}_{\mathrm{C}}\right)$. Temperature regime: heating rate-10 deg/min and cooling rate of $40 \mathrm{deg} / \mathrm{min}, \mathrm{P}_{\mathrm{n}}$ - thermal arrest with standard deviation (SD), ${ }^{\circ} \mathrm{C} ; \Delta \mathrm{H}_{\mathrm{n}}$ - corresponding enthalpy change with standard deviation, $\mathrm{J} \mathrm{g}^{-1}$; "-" missing thermal arrest in the respective run.

\begin{tabular}{|c|c|c|c|c|c|c|}
\hline No & $\begin{array}{c}P_{1} \pm S D \\
\left({ }^{\circ} \mathrm{C}\right)\end{array}$ & $\begin{array}{c}\Delta \mathrm{H}_{1} \pm \mathrm{SD} \\
\left(\mathrm{J} \mathrm{g}^{-1}\right)\end{array}$ & $\begin{array}{c}\mathrm{P}_{2} \pm \mathrm{SD} \\
\left({ }^{\circ} \mathrm{C}\right)\end{array}$ & $\begin{array}{c}\Delta \mathrm{H}_{2} \pm \mathrm{SD} \\
\left(\mathrm{Jg}^{-1}\right)\end{array}$ & $\begin{array}{c}P_{3} \pm S D \\
\left({ }^{\circ} \mathrm{C}\right)\end{array}$ & $\begin{array}{c}\Delta \mathrm{H}_{3} \pm \mathrm{SD} \\
\quad\left(\mathrm{J} \mathrm{g}^{-1}\right)\end{array}$ \\
\hline $1^{B}{ }_{h}$ & $574.7 \pm 0.9$ & $7.6 \pm 0.5$ & - & - & - & - \\
\hline $1_{c}^{B}$ & $580.7 \pm 0.1$ & $-5.2 \pm 0.3$ & $586.8 \pm 0.3$ & $0.6 \pm 0.7$ & $\approx 1200$ & $3.23 \pm 0.6$ \\
\hline $2_{h}^{B}$ & $574.6 \pm 0.2$ & $6.7 \pm 0.7$ & - & - & - & - \\
\hline $2^{B}{ }_{c}$ & $574.2 \pm 3.6$ & $-4.1 \pm 0.3$ & $594.2 \pm 0.1$ & $-0.5 \pm 0.2$ & - & - \\
\hline $4_{h}^{B}$ & $574.5 \pm 0.4$ & $6.4 \pm 0.6$ & - & - & - & - \\
\hline $4^{B}{ }_{C}^{B}$ & $580.5 \pm 0.4$ & $-3.9 \pm 0.1$ & $588.2 \pm 0.1$ & $-0.2 \pm 0.1$ & $\approx 1200$ & $1.3 \pm 0.4$ \\
\hline
\end{tabular}

Table 6. Results of DSC experiments with Al-Si-Zr sample No. $3^{\mathrm{B}}$ at heating $\left(\mathrm{No}_{\mathrm{h}}\right)$ and cooling $\left(\mathrm{No}_{\mathrm{C}}\right)$. Temperature regime: heating rate- $10 \mathrm{deg} / \mathrm{min}$ and cooling rate of $40 \mathrm{deg} / \mathrm{min}, \mathrm{P}_{\mathrm{n}}$ - thermal arrest with standard deviation (SD), ${ }^{\circ} \mathrm{C} ; \Delta \mathrm{H}_{\mathrm{n}}$ - corresponding enthalpy change with standard deviation, $\mathrm{J} \mathrm{g}^{-1}$; “-" missing thermal arrest at the respective run.

\begin{tabular}{|c|c|c|c|c|c|c|}
\hline No & $\begin{array}{c}\mathbf{P}_{1} \\
\left({ }^{\circ} \mathrm{C}\right)\end{array}$ & $\begin{array}{c}\Delta \mathrm{H}_{1} \pm \mathrm{SD} \\
\left(\mathrm{Jg}^{-1}\right)\end{array}$ & $\begin{array}{c}\mathrm{P}_{2} \\
\left({ }^{\circ} \mathrm{C}\right)\end{array}$ & $\begin{array}{c}\Delta \mathrm{H}_{2} \pm \mathrm{SD} \\
\left(\mathrm{Jg}^{-1}\right)\end{array}$ & $\begin{array}{c}\mathrm{P}_{3} \\
\left({ }^{\circ} \mathrm{C}\right)\end{array}$ & $\begin{array}{c}\Delta \mathrm{H}_{3} \pm \mathrm{SD} \\
\quad\left(\mathrm{Jg}^{-1}\right)\end{array}$ \\
\hline $3^{B}{ }_{h}$ & $575.8 \pm 0.4$ & $17.8 \pm 13.3$ & $\begin{array}{c}1475.5 \pm \\
3.5\end{array}$ & $73.4 \pm 74$ & - & - \\
\hline $3^{B}{ }_{c}$ & $572.1 \pm 6.9$ & $\begin{array}{c}-27.7 \pm \\
21.7\end{array}$ & - & - & $\begin{array}{c}1486.7 \pm \\
1.6\end{array}$ & $-333 \pm 34$ \\
\hline
\end{tabular}

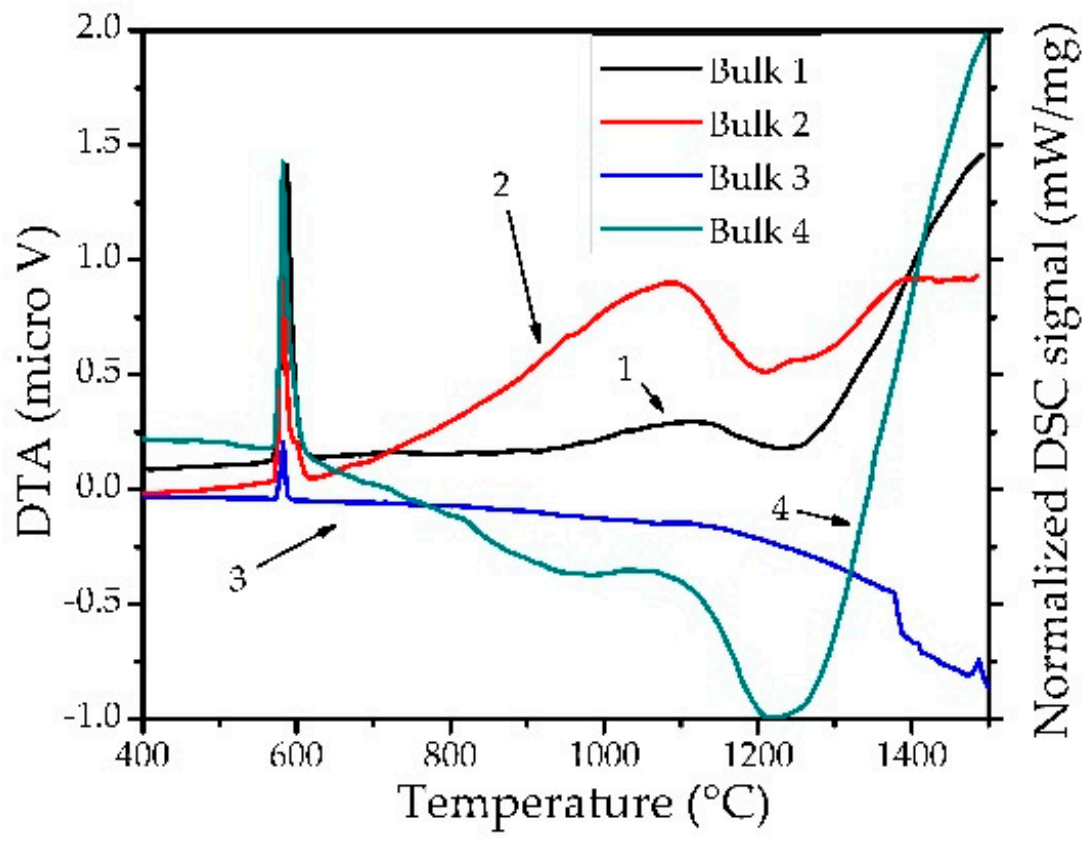

Figure 5. DTA curves at heating (first run) of bulk samples nos. $1^{\mathrm{B}}, 2^{\mathrm{B}}, 3^{\mathrm{B}}$, and DSC curve of bulk no. $4^{\mathrm{B}}$, normalized by factor 50 . DTA signal $(\mu \mathrm{V})$ along the ordinate and temperature $\left({ }^{\circ} \mathrm{C}\right)$ along the abscissa are plotted. 


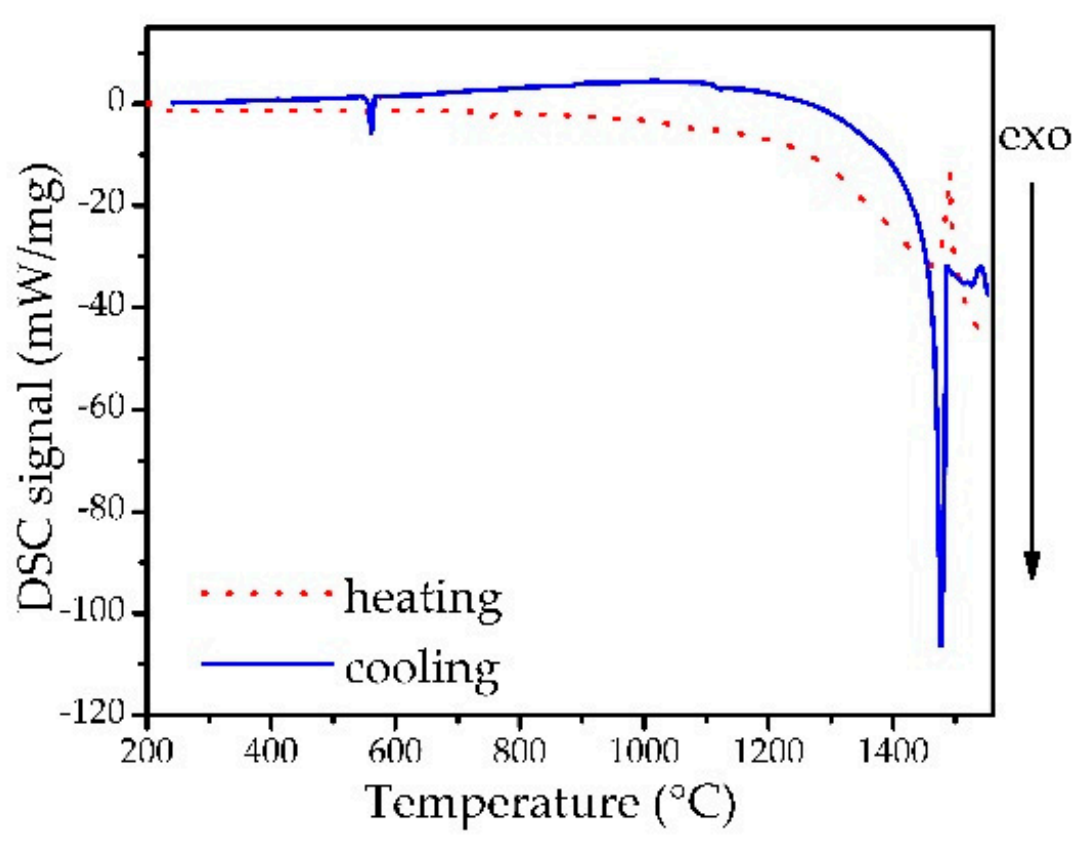

Figure 6. DSC curves at heating and cooling of bulk number 3. DSC signal (mW/mg) along the ordinate and temperature $\left({ }^{\circ} \mathrm{C}\right)$ along the abscissa are plotted.

As predictable, the strongest thermal arrests (registered with all samples) correspond to the eutectic reaction in the Al-Si system:

$$
\mathrm{L} \leftrightarrow(\mathrm{Al})+(\mathrm{Si})
$$

In Equation (2), $\mathrm{L}$ is for the liquid phase, (Al)—for the face centred cubic aluminium (or FCC) phase, and (Si) - for the tetragonal silicon phase. The enthalpy changes $\left(\Delta \mathrm{H}_{\mathrm{i}}\right.$, $\mathrm{J} \mathrm{g}^{-1}$ ) related to the corresponding thermal effects have been calculated.

Thermal effects with the participation of the $\mathrm{Al}_{3} \mathrm{Zr}$ might be expected at around $660^{\circ} \mathrm{C}$, due to the peritectic reaction:

$$
\mathrm{Al}_{3} \mathrm{Zr}+\mathrm{L} \leftrightarrow(\mathrm{Al})
$$

Nevertheless, such thermal arrests have not been observed clearly, which is easily understandable taking into account that peritectic reactions are kinetically hindered. Moreover, in the case under consideration the compositional difference between two of the phases is extremely small (the zirconium content is 0.08 mole fractions for (Al) and 0.03 mole fractions for $\mathrm{L}$ ) [15]. In addition the envisaged $\mathrm{Al}_{3} \mathrm{Zr}$ fraction in the alloys is also rather tiny.

As one can see (Tables 5 and 6 ), the strongest thermal effect $\left(\mathrm{P}_{1}\right)$ has been registered with all bulk samples. The $\left(\mathrm{P}_{1}\right)$ peaks correspond to the binary Al-Si eutectic reaction (Equation (2)), and are situated at around $572-580{ }^{\circ} \mathrm{C}$ (with standard deviations around $1{ }^{\circ} \mathrm{C}$ ). The eutectic peak temperatures measured by DSC at cooling are reasonably lower $\left(572.1^{\circ} \mathrm{C}\right)$ than these registered at heating $\left(575.8^{\circ} \mathrm{C}\right)$. These findings confirm that the chemical and the phase compositions of the alloys are near to the Al-Si eutectic point.

The thermal arrests $\mathrm{P}_{2}$ and $\mathrm{P}_{3}$ have been observed at the DTA studies only (Table 5).

Namely, $\mathrm{P}_{2}$ effects (Table 5) have been registered at runs nos. $1^{\mathrm{B}}{ }_{\mathrm{c}}, 2^{\mathrm{B}}{ }_{\mathrm{c}}, 4^{\mathrm{B}}{ }_{\mathrm{c}}$ (Figure 5). These very feeble peaks are related to the crossing of the liquidus at cooling, before reaching the eutectic temperature.

The thermal effect $\mathrm{P}_{3}$ (Table 5) is observed with the DTA cooling runs of samples $1^{\mathrm{B}}{ }_{\mathrm{c}}$ and $4^{\mathrm{B}}{ }_{\mathrm{c}}$ at around $1200^{\circ} \mathrm{C}$. This effect could be related to the invariant reaction of Equation (4) taking place at $1275^{\circ} \mathrm{C}$ according to $[9,13]$.

$$
\mathrm{Zr}_{5} \mathrm{Al}_{4}+\mathrm{Zr}_{2} \mathrm{Al}_{3} \leftrightarrow \mathrm{ZrAl}
$$


$\mathrm{P}_{2}$ appears at $1475.5^{\circ} \mathrm{C}$ (at heating, Table 6) and $\mathrm{P}_{3}$ at $1486.7^{\circ} \mathrm{C}$. These temperatures might be related to the high-temperature eutectic reaction of Equation (5) [11]:

$$
\mathrm{L} \leftrightarrow \mathrm{Al}_{4} \mathrm{Zr}_{5}+\mathrm{Al}_{3} \mathrm{Zr}_{2}
$$

\subsection{Optical and Scanning Electron Microscope Studies. Microhardness Tests}

The microstructure of the ternary systems was observed using optical microscope. A cross-section of ribbon number 3 can be seen in Figure 7. It reveals that during the casting process two different microstructures are formed. The first structural zone corresponds to the wheel-side surface (WS - wheel-side) of the ribbon and the second one to that exposed to air (AS-air-side). The microstructure at the WS has smaller phase sizes (upper side of the picture) than that of the AS (the lower side of the picture).

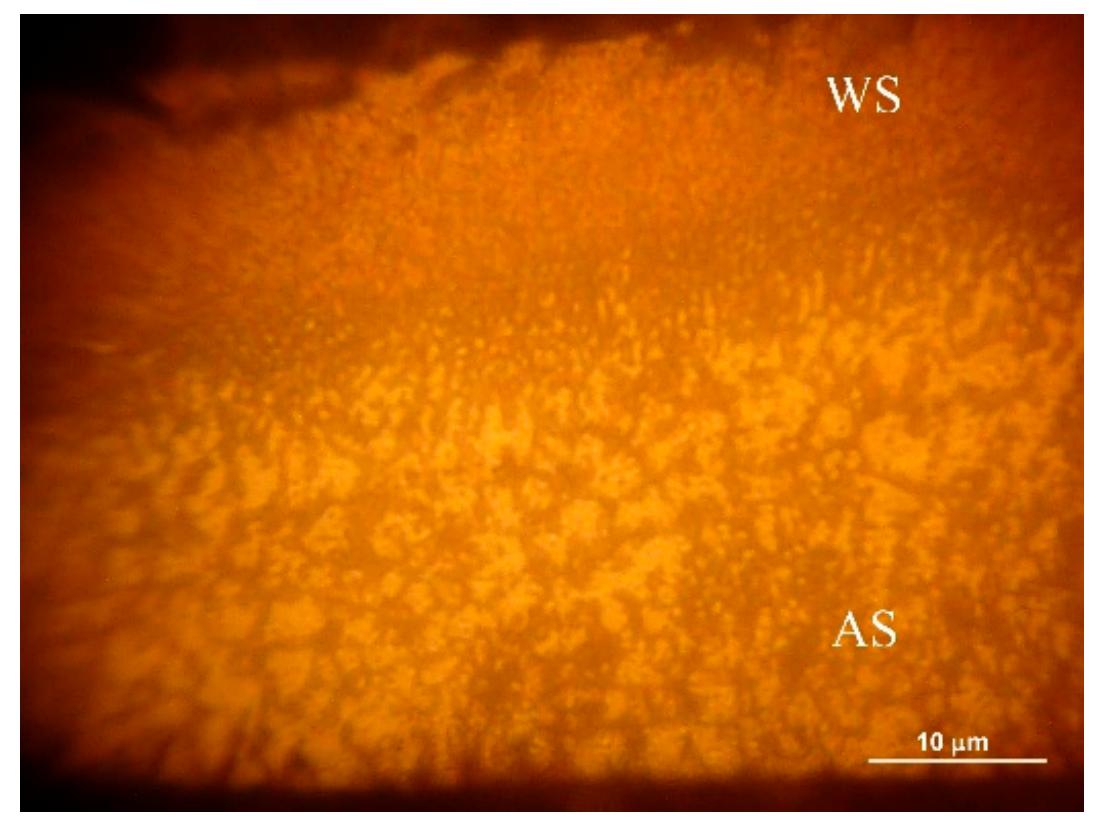

Figure 7. Cross-section optical image of the ribbon microstructure. Upper zone is at the side of the cooling wheel (WS) and presents smaller grain sizes, while the lower zone is at the air side (AS) and the grain sizes are bigger.

A micrograph of bulk alloy number 3 is shown in Figure 8. The microstructure is much coarse than that of the corresponding ribbon.

The average length of the Al-Si-Zr compound, measured by SEM, is around $100 \mu \mathrm{m}$ as it can be seen in Figure 9. This finding is in agreement with Gao et al. [12]

The oxide layer and the composition of the ternary compound of bulk samples before and after high temperature oxidation have been studied as well. The thermogravimetric oxidation was carried out at $540^{\circ} \mathrm{C}$ for $90 \mathrm{~min}$. The atomic percent of oxygen was estimated by SEM-EDX. Before oxidation it is $60.48 \pm 3.26$, while after oxidation it is $63.37 \pm 1.35$.

In order to determine the composition of the ternary compound atomic concentrations of $\mathrm{Al}, \mathrm{Si}$ and $\mathrm{Zr}$ were recalculated after subtracting the respective oxygen content and normalizing the obtained data to $100 \%$. Average ternary composition before oxidation, acquired in that way, corresponds to the formula $\mathrm{Al}_{72} \mathrm{Si}_{10} \mathrm{Zr}_{17}$ while after oxidation-to $\mathrm{Al}_{42} \mathrm{Si}_{37} \mathrm{Zr}_{21}$ (Table 7). It is obvious that the aluminum concentration decreases while the Si-concentration increases, probably due to dissolution of aluminum from the ternary phase to the matrix and diffusion of Si into ternary phase. Those ternary compounds have a certain homogeneity range. The described change is visualized in Figure 10. 


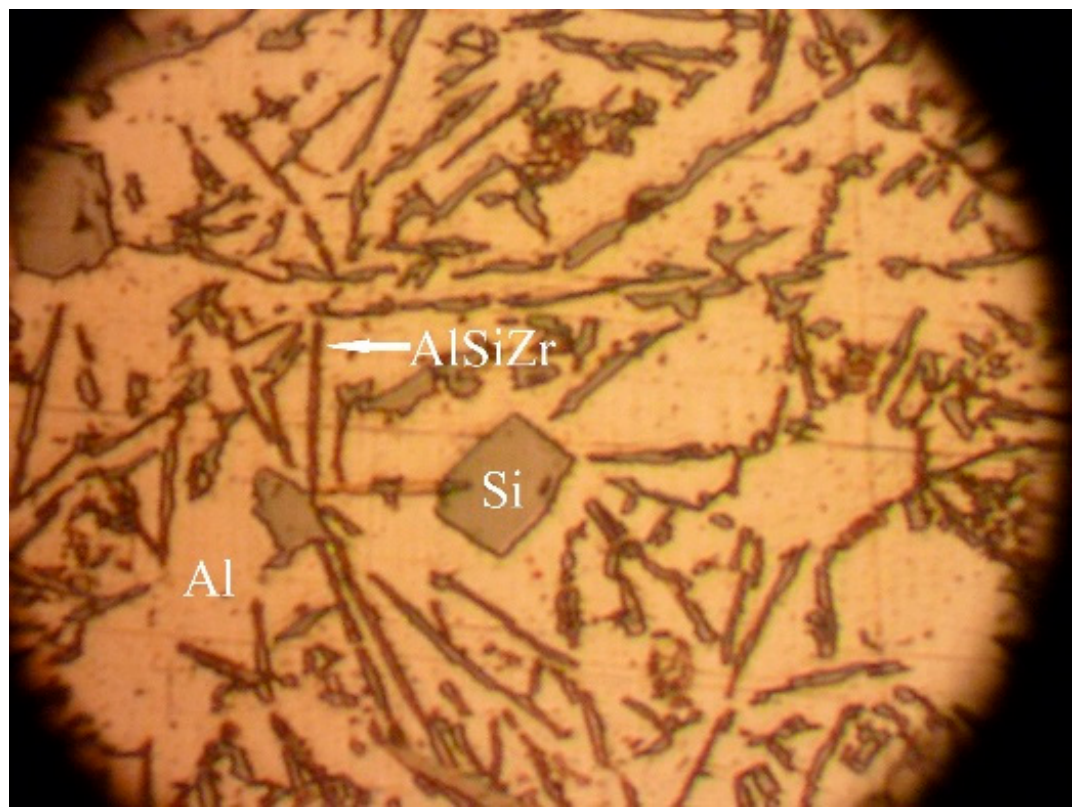

Figure 8. Microstructure of bulk alloy number 3 taken by optical microscope-under eutectic structure with pronounced aluminum phase (Al), silicon phases ( $\mathrm{Si}$ ) in the form of plates, and an intermetallics (Al-Si-Zr) in the form of darker flake-like morphology.

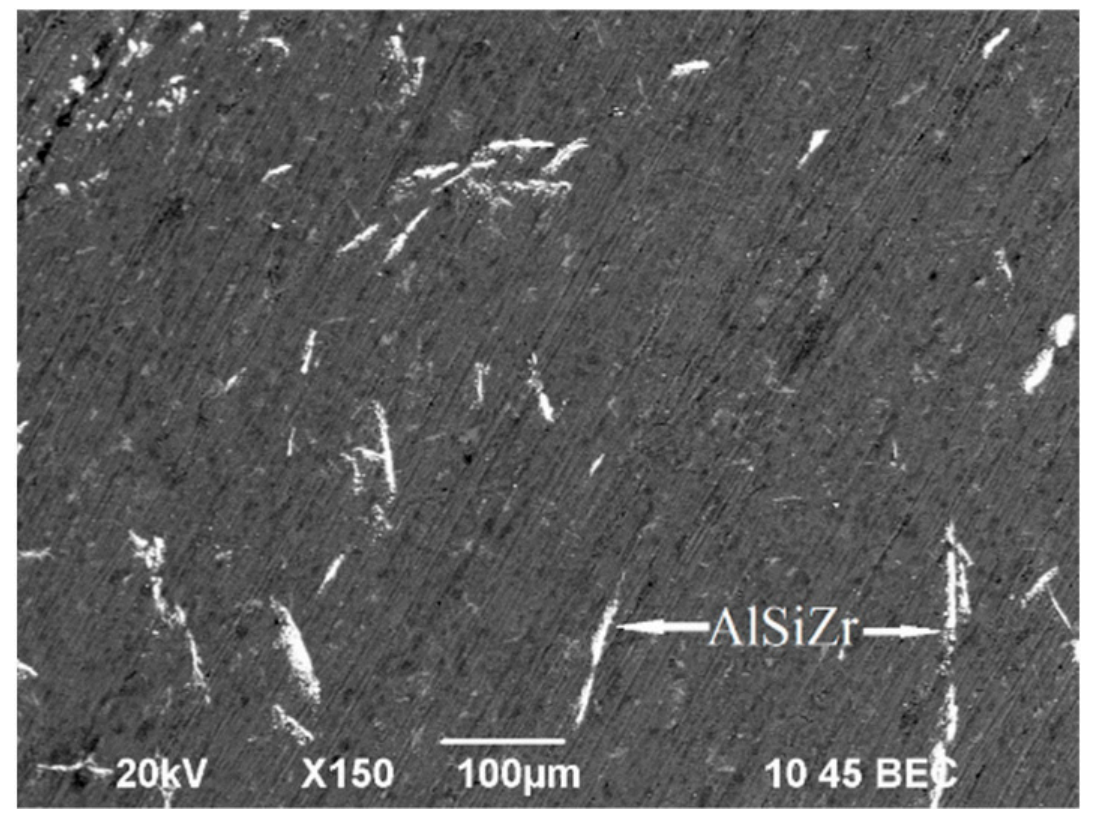

Figure 9. Microstructure of bulk alloy number 3 taken by electron microscope in back scattered electrons-Al-matrix in darker and flake-like morphology of AlSiZr intermetallics with average length around $100 \mu \mathrm{m}$. 
Table 7. Relative Al, Si and $\mathrm{Zr}$ content of bulk alloys before and after high temperature oxidation. No-consecutive number of the bulk alloy; Sp.-number of the spectrum; concentration of $\mathrm{Al}, \mathrm{Si}$ and $\mathrm{Zr}$ in the ternary compound before and after oxidation, in atomic percent; Average-average composition of all spectrums with the respective standard deviation (SD).

\begin{tabular}{|c|c|c|c|c|c|c|c|c|}
\hline \multirow[b]{2}{*}{ No } & \multirow[b]{2}{*}{ Sp. } & \multicolumn{3}{|c|}{ Before Oxidation } & \multirow[b]{2}{*}{ Sp. } & \multicolumn{3}{|c|}{ After Oxidation } \\
\hline & & $\begin{array}{c}\mathrm{Al} \\
\text { (At. \%) }\end{array}$ & $\begin{array}{c}\mathrm{Si} \\
\text { (At.\%) }\end{array}$ & $\begin{array}{c}\mathrm{Zr} \\
\text { (At.\%) }\end{array}$ & & $\begin{array}{c}\mathrm{Al} \\
(\mathrm{At} . \%)\end{array}$ & $\begin{array}{c}\mathrm{Si} \\
(\text { At. } \%)\end{array}$ & $\begin{array}{c}\mathrm{Zr} \\
\text { (At.\%) }\end{array}$ \\
\hline \multirow{5}{*}{$1^{\mathrm{B}}$} & 26 & 76.66 & 11.90 & 11.44 & 1 & 42.56 & 34.62 & 22.82 \\
\hline & 27 & 70.39 & 18.37 & 11.24 & 3 & 49.03 & 32.79 & 18.18 \\
\hline & - & - & - & - & 4 & 41.29 & 47.11 & 11.61 \\
\hline & - & - & - & - & 6 & 42.56 & 36.20 & 21.24 \\
\hline & - & - & - & - & 7 & 49.89 & 32.63 & 17.48 \\
\hline \multirow{3}{*}{$2^{\mathrm{B}}$} & 32 & 75.98 & 8.49 & 15.54 & 9 & 44.12 & 34.86 & 21.02 \\
\hline & 33 & 73.68 & 8.24 & 18.08 & 11 & 40.97 & 36.44 & 22.58 \\
\hline & - & - & - & - & 12 & 39.52 & 37.36 & 23.12 \\
\hline \multirow{4}{*}{$3^{\mathrm{B}}$} & 35 & 64.47 & 11.08 & 24.44 & 13 & 38.23 & 38.01 & 23.76 \\
\hline & 36 & 69.02 & 10.70 & 20.28 & 15 & 43.90 & 35.08 & 21.02 \\
\hline & 37 & 71.01 & 10.21 & 18.78 & 16 & 39.83 & 37.56 & 22.61 \\
\hline & - & - & - & - & 17 & 36.83 & 39.31 & 23.85 \\
\hline \multirow{4}{*}{$4^{\mathrm{B}}$} & 39 & 64.84 & 10.49 & 24.67 & 19 & 39.96 & 34.84 & 25.20 \\
\hline & 40 & 74.43 & 8.46 & 17.11 & 20 & 35.14 & 40.28 & 24.58 \\
\hline & 41 & 75.75 & 8.15 & 16.09 & 21 & 48.79 & 31.31 & 19.90 \\
\hline & - & 80.00 & 6.94 & 13.06 & - & - & - & - \\
\hline Average & - & 72.38 & 10.28 & 17.34 & - & 42.18 & 36.56 & 21.26 \\
\hline $\mathrm{SD}$ & - & 4.93 & 3.09 & 4.59 & - & 4.25 & 3.70 & 3.35 \\
\hline
\end{tabular}

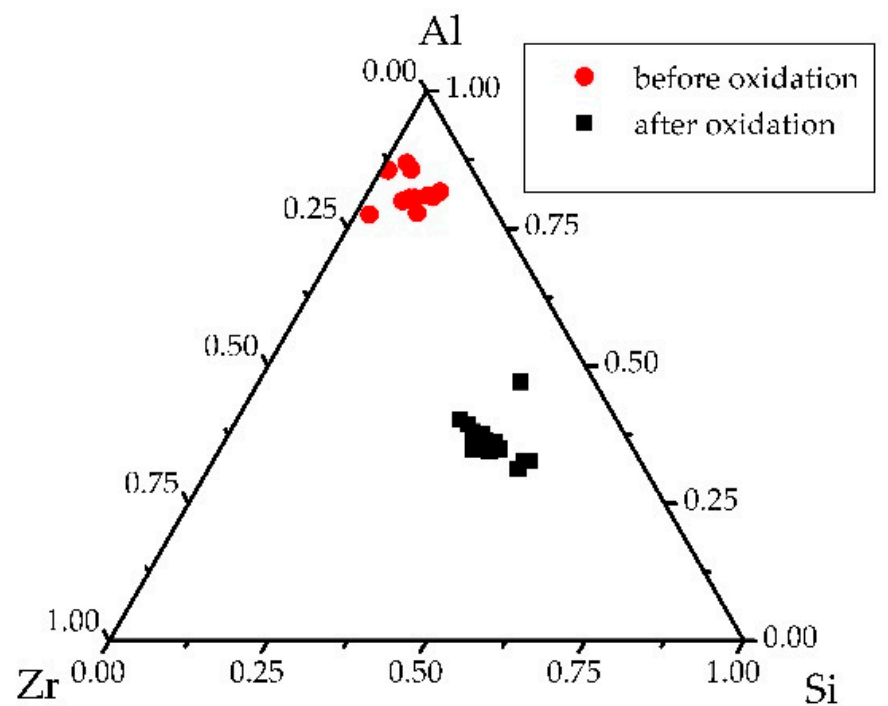

Figure 10. Schematic ternary compound composition (in atomic percents) revealed by SEM-EDS before and after the oxidation at $540{ }^{\circ} \mathrm{C}$ for $90 \mathrm{~min}$. The circles $(\bullet)$ represent its composition before oxidation, while the rectangular $(\boldsymbol{\square})$ represent its composition after oxidation.

The ternary compound $\mathrm{Al}_{72} \mathrm{Si}_{10} \mathrm{Zr}_{17}$ suffered not only composition changes (see above) but microstructure changes as well. Before oxidation it looks like a compact particle, while after oxidation its microstructure is flake-like (Figures 11 and 12). 


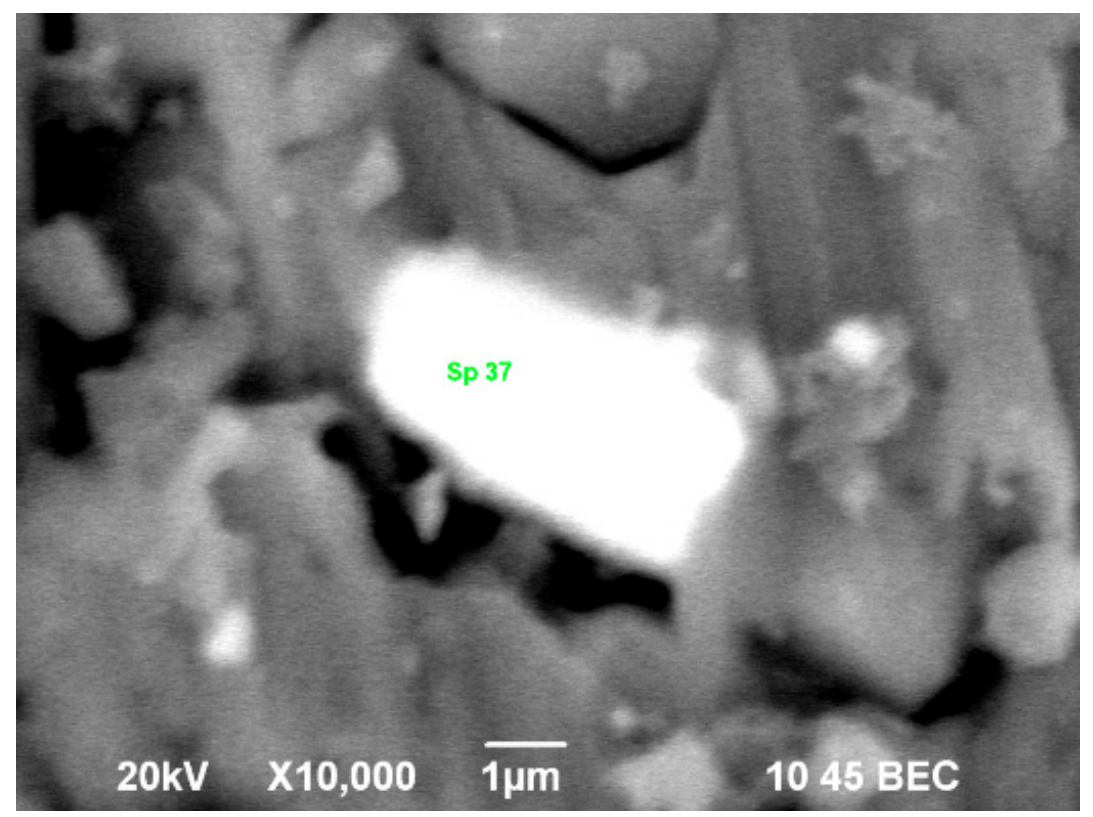

Figure 11. SEM image in back scattered electrons of bulk number 2 before oxidation with composition of the intermetallics (spectrum 37) shown in Table 7. The bright particle (Sp 37) is associated with the compound $\mathrm{Al}_{72} \mathrm{Si}_{10} \mathrm{Zr}_{17}$.

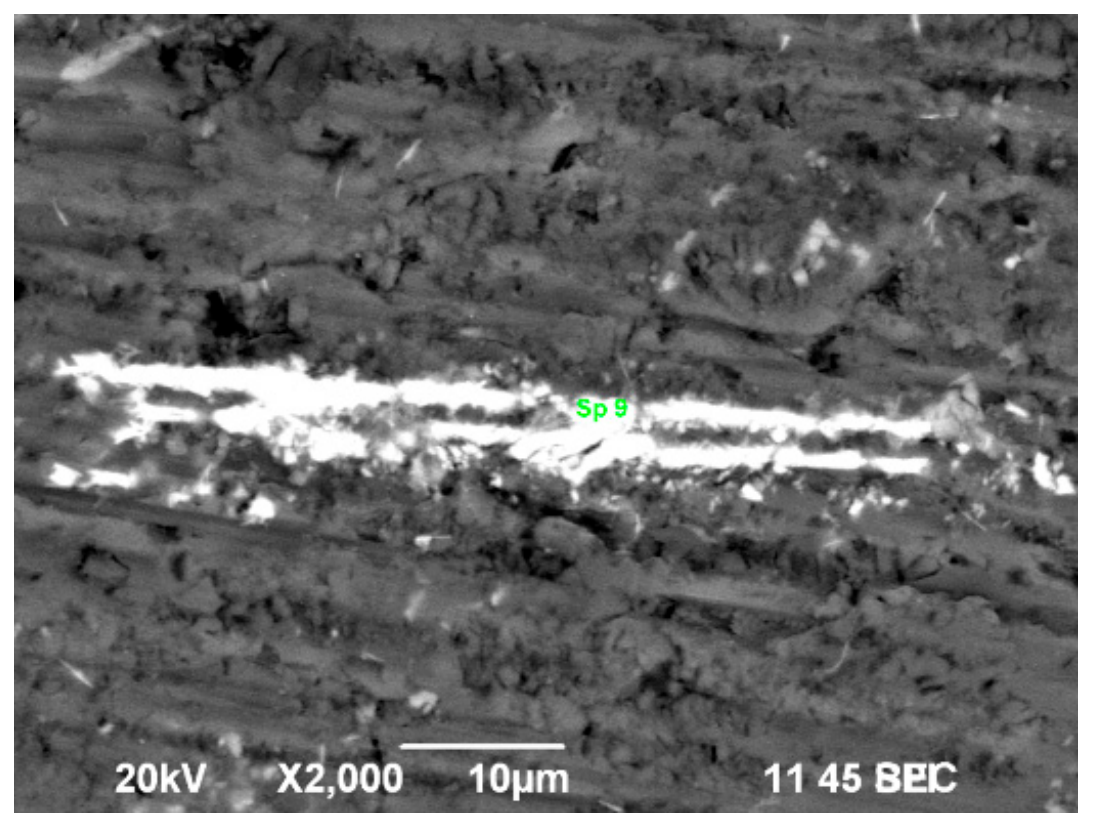

Figure 12. SEM image in back scattered electrons of bulk number 2 after oxidation with composition of the intermetallics (spectrum 9) shown in Table 7. The particle (Sp 9) corresponds to the formulae $\mathrm{Al}_{42} \mathrm{Si}_{37} \mathrm{Zr}_{21}$ without counting the oxygen content.

Microhardness tests have been done with all samples. The results have been averaged from eight measurements for each sample and are introduced in Table 8. Vickers hardness $\left(\mathrm{HV}, \mathrm{kgf} / \mathrm{mm}^{2}\right)$ is converted to MPa in SI system. It can be noticed that the ribbon samples have values of the Vickers hardness twice as big than that of the bulk samples due to the rapidly solidification process. 
Table 8. Vickers hardness $\left(\mathrm{HV}, \mathrm{kgf} / \mathrm{mm}^{2}\right)$ measured of bulk $\left(\mathrm{N}^{\mathrm{B}}\right)$ and ribbon $\left(\mathrm{N}^{\mathrm{R}}\right)$ samples, $\mathrm{SD}$-standard deviation, $\mathrm{H}-$ hardness $(\mathrm{MPa})$.

\begin{tabular}{cccccc}
\hline $\mathbf{N}^{\mathbf{B}}$ & $\begin{array}{c}\mathbf{H V} \pm \mathbf{S D} \\
\left(\mathbf{k g f} / \mathbf{m m}^{\mathbf{2}}\right)\end{array}$ & $\begin{array}{c}\mathbf{H} \pm \mathbf{S D} \\
\mathbf{( M P a )}\end{array}$ & $\mathbf{N}^{\mathbf{R}}$ & $\begin{array}{c}\mathbf{H V} \pm \mathbf{S D} \\
\mathbf{( k g f / \mathbf { m m } ^ { 2 } \mathbf { ) }}\end{array}$ & $\begin{array}{c}\mathbf{H} \pm \mathbf{S D} \\
\mathbf{( M P a})\end{array}$ \\
\hline $1^{\mathrm{B}}$ & $54 \pm 3$ & $533 \pm 32$ & $1^{\mathrm{R}}$ & $99 \pm 11$ & $974 \pm 105$ \\
$2^{\mathrm{B}}$ & $55 \pm 5$ & $538 \pm 53$ & $2^{\mathrm{R}}$ & $100 \pm 5$ & $1077 \pm 46$ \\
$3^{\mathrm{B}}$ & $54 \pm 4$ & $534 \pm 39$ & $3^{\mathrm{R}}$ & $102 \pm 12$ & $996 \pm 116$ \\
$4^{\mathrm{B}}$ & $48 \pm 2$ & $473 \pm 22$ & $4^{\mathrm{R}}$ & $121 \pm 2$ & $1191 \pm 20$ \\
\hline
\end{tabular}

\section{Conclusions}

A number of experiments with $\mathrm{Al}-\mathrm{Si}-\mathrm{Zr}$ bulk alloys and rapidly solidified ribbons were done. Two oxidation kinetics stages were distinguished. Rate-controlling processes are: chemical reaction velocity, initially (i.e., for the first stage), and oxygen diffusion (for longer times). Activation energy values were calculated for both cases, separately.

A ternary compound corresponding to the formula $\mathrm{Al}_{72} \mathrm{Si}_{10} \mathrm{Zr}_{17}$ was identified in the metallic samples. It also suffers oxidation and its composition changed to $\mathrm{Al}_{42} \mathrm{Si}_{37} \mathrm{Zr}_{21}$ (without counting the oxygen content).

It was observed that ribbons had bigger hardness values than the respective bulk samples due to the microstructure achieved at rapid solidification.

Author Contributions: Conceptualization, G.V. and S.Y.; Formal analysis, D.K. and G.V.; Funding acquisition, R.M.; Investigation, D.K., G.V. and N.M.; Methodology, G.V.; Project administration, G.V.; Software, D.K.; Supervision, G.V.; Validation, D.K., G.V. and N.M.; Visualization, N.M.; Writingoriginal draft, D.K., G.V. and N.M.; Writing-review and editing, N.M. All authors have read and agreed to the published version of the manuscript.

Funding: This research was funded by the NATIONAL SCIENTIFIC PROGRAM "Young Scientists and Postdoctoral Candidates" of Bulgarian Ministry of Education and Science.

Institutional Review Board Statement: Not applicable.

Informed Consent Statement: Not applicable.

Data Availability Statement: The datasets used and analyzed during the current study are available from the corresponding author on reasonable request. All data are in the form of tables and figures.

Acknowledgments: The authors are very grateful to Jolanta Romanowska from Politechnika Rzeszowska, Rzeszow, Poland for SEM-EDS analysis.

Conflicts of Interest: The authors declare that there is no conflict of interest regarding the publication of this paper. The funders had no role in the design of the study; in the collection, analyses, or interpretation of data; in the writing of the manuscript, or in the decision to publish the results.

\section{References}

1. Çadırlı, E.; Tecer, H.; Şahin, M.; Yılmaz, E.; Kırındı, T.; Gündüz, M. Effect of heat treatments on the microhardness and tensile strength of Al-0.25 wt.\% Zr alloy. J. Alloys Compd. 2015, 632, 229-237. [CrossRef]

2. Li, Q.; Ma, X.; Li, B.; Ma, J.; Feng, X.; Pei, R.; Liu, J. Influences of different Zr/Sc ratios on microstructure and mechanical properties of Al-2Si alloy. J. Rare Earths 2021, 39, 105-112. [CrossRef]

3. Andrzejczuk, M.; Lewandowska, M.; Latuch, J.; Kurzydłowski, K.J. Multiscale characterization of nanostructured Al-Si-Zr alloys obtained by rapid solidification method. J. Mater. Sci. 2011, 46, 5454-5459. [CrossRef]

4. Bao, G.; Zuo, M.; Li, D.; Li, Y.; Liu, X. The improvement of microstructures and mechanical properties of near eutectic Al-Si multicomponent alloy by an Al-8Zr-2P master alloy. Mater. Sci. Eng. A 2012, 531, 55-60. [CrossRef]

5. Dang, J.; Huang, Y.; Cheng, J. Effect of Sc and Zr on microstructures and mechanical properties of as-cast Al-Mg-Si-Mn alloys. T. Nonferr. Metal Soc. 2009, 19, 540-544. [CrossRef]

6. Bevilaqua, W.L.; Stadtlander, A.R.; Froehlich, A.R.; Lemos, G.V.B.; Reguly, A. High-temperature mechanical properties of cast Al-Si-Cu-Mg alloy by combined additions of cerium and zirconium. Mater. Res. Express. 2020, 7, 026532. [CrossRef]

7. Reihanian, M.; Ranjbar, K.; Rashno, S. Microstructure and Impression Creep behaviour of Al-7Si-0.3Mg alloy with Zr addition. Met. Mater. Int. 2020, 27, 2530-2540. [CrossRef] 
8. Rahimian, M.; Amirkhanlou, S.; Blake, P.; Ji, S. Nanoscale Zr-containing precipitates; a solution for significant improvement of high-temperature strength in Al-Si-Cu-Mg alloys. Mater. Sci. Eng. A 2018, 721, 328-338. [CrossRef]

9. McPherson, D.J.; Hansen, M. The System Zr-Al. Trans. ASM 1954, 46, 354-374.

10. Murray, J.L.; McAlister, A.J. The Al-Si (Aluminum-Silicon) system. Bull. Alloy Phase Diagr. 1984, 5, 74-84. [CrossRef]

11. Massalski, T. ASM CD-ROM. In Binary Phase Diagrams, 2nd ed.; ASM International: Almere, The Netherlands, 1996.

12. Tong, G.; Dakuia, L.; Zuoshanb, W.; Xiangfaa, L. Evolution, microhardness of ZrAlSi intermetallic and its impact on the elevated-temperature properties in Al-Si alloys. Mater. Sci. Eng. A 2012, 552, 523-529. [CrossRef]

13. Wang, T.; Jin, Z.; Zhao, J.C. Thermodynamic assessment of the Al-Zr binary system. JPE 2001, 22, 544-551. [CrossRef]

14. Litynska, L.; Abou-Ras, D.; Kostorz, G.; Duetkiewicz, J. TEM and HREM study of $\mathrm{Al}_{3} \mathrm{Zr}$ precipitates in an Al-Mg-Si-Zr alloy. J. Microsc. 2006, 223, 182-184. [CrossRef]

15. Mondolfo, L.F. Aluminum Alloys: Structure and Properties; Butterworths and Co., Ltd.: London, UK, 1976. [CrossRef]

16. Liu, Y.; Tang, M.; Wu, C.; Wang, J.; Su, X. Progress on phase equilibria of the AlSiZr system at 700 and $900{ }^{\circ} \mathrm{C}$. J. Alloys Compd. 2017, 693, 357-365. [CrossRef]

17. Schob, O.; Nowotny, H.; Benesovsky, F. The Ternary Systems (Titanium, Zirconium, Hafnium)-Aluminum-Silicon. Planseeber. Pulvermetall. 1962, 10, 65-71.

18. Beck, A.F.; Heine, M.A.; Caule, E.J.; Pryor, M.J. The kinetics of the oxidation of $\mathrm{Al}$ in oxygen at high temperature. Corros. Sci. 1967, 7, 1-22. [CrossRef]

19. Petrova, A.; Stefanov, G.; Yaneva, S.; Avdeev, G.; Miteva, A.; Petrov, R. Influence of the inert particle additives on the properties of the nano-microcrystalline alloys on based on Al-Fe-V-Si. Metallurgist 2020, 64, 3-4. [CrossRef]

20. Stoichev, N.; Petrov, K.; Yaneva, S.; Kovachev, P.; Tzvetanova, N. Micro-structural development in Al-Si microcrystalline alloys. Mater. Sci. Eng. A 2002, 337, 12-16. [CrossRef]

21. Yaneva, S.; Stojanova, L.; Markow, T. Oxidation of Solid Aluminium Silicon Alloys in Air. Cryst. Res. Technol. 1987, 22, 251-258. [CrossRef]

22. Lins, V.F.C.; Paula e Silva, E.M. Autocorrelation treatment of thermogravimetric data with the cochrane-orcutt method. Braz. J. Chem. Eng. 1997, 14, 179-184. [CrossRef]

23. Knoll, A.; Smigiel, E.; Broll, N.; Cornet, A. Study of high temperature oxidation kinetics of steel using grazing X-ray reflectometry. In Advances in X-ray Analysis (AXA)-Denver X-ray Conferences; JCPDS-International Centre for Diffraction Data: Newtown Square, PA, USA, 1999; pp. 170-178.

24. Kiradzhiyska, D.; Drajewicz, M.; Romanowska, J.; Volšak, D.; Gandova, V.; Vassilev, G. Thermochemical and electron microscope studies of fast-cooled cast Al-Si-Zr ribbons and Al-Cu-Nd alloys. Basic Inf. 2014, 1, 15-26.

25. Stefanov, G.; Kiradzhiyska, D.; Avdeev, G. High-temperature oxidation of Al-Si-Zr alloys. In Proceedings of the NDT Days 2013, Sozopol, Bulgaria, 17-21 June 2013; Volume 2, pp. 305-308. (In Bulgarian).

26. Kiradzhiyska, D.; Vassilev, G.; Mantcheva, R. Thermochemical studies of Al-Si-Zr alloys. In Proceedings of the Science and Youth Conference, Plovdiv, Bulgaria, 10-12 April 2014; pp. 319-322. 